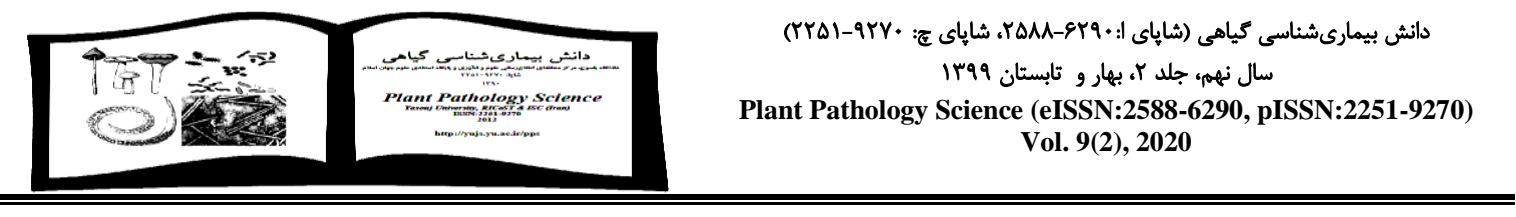

Extensional Article

\title{
Fungal diseases of hazelnut in Iran
}

\section{SOGHRA GHASEMI-DOODARAN, MEHDI DAVARI ${ }^{\bowtie}$}

Department of Plant Protection, Faculty of Agriculture and Natural Resources,

University of Mohaghegh Ardabili, Ardabil, Iran

Received: 10.16.2020

Accepted: 01.24.2021

Ghasemi-Doodaran S, Davari M (2020) Fungal diseases of hazelnut in Iran. Plant Pathology Science 9(2):85-94. DOI: 10.2982/PPS.9.2.85.

\begin{abstract}
Hazelnut tree has natural habitats in northwestern Iran in the forests of Ardabil and Gilan provinces. Decline disease is a threatening agent of hazelnut trees in these areas. Symptoms of the disease include weakness, reduced growth, leaf fall and dieback of the branches, branch and trunk canker and root rot that eventually lead to the gradual death or decline of the tree. In Iran the fungi cause hazelnut decline disease, Diaporthe amygdali, and Cytospora fuckelii as canker and Fusarium semitectum, F. lateritium, F. anthophilum and Armillaria mellea as root rot causative agents. This article describes symptoms of hazelnut decline in Iran, pathogenic fungi and management strategies.
\end{abstract}

Key words: Dieback, Canker, Fusarium, Diaporthe, Armillaria.

Corresponding author: mdvari@uma.ac.ir 


\section{مقاله ترويجى \\ بيمارىهاى قارجى فندق در ايران \\ صغرى قاسمى دودران ، مهدى داورى}

كروه گياهيزشكى، دانشكده كشاورزى و منابع طبيعى، دانشعاه محقق اردبيلى، اردبيل

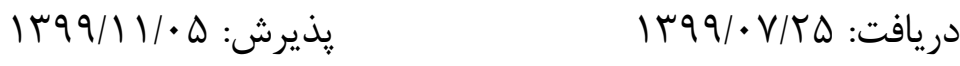

قاسمى دودران ص، داورى م (9 (1) بيمارىهاى قارجى فندق در ايران. دانش بيمارىشناسى گياهى

DOI:10.2982/PPS.9.2.85. $. \wedge \Delta-9 \uparrow:(r) q$

جكيده

درخت فندق، داراى رويشگاههاى طبيعى در شمال غـرب ايـران در جنگل هـاى اسـتانهاى اردبيـل و كيلان است. بيمارى زوال يك عامل تهديدكننده درختان فندق در اين ناحيه است. نشانههاى بيمارى به شكل ضعف عمومى، كاهش رشد، برگريزى و سرخشكيدگى شاخهها، شـانكر روى شـاخه و تنسه و

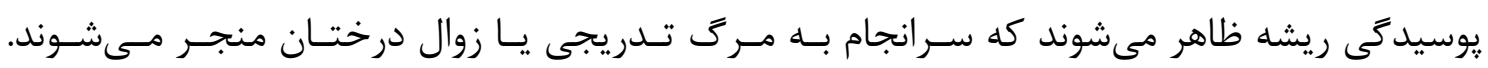

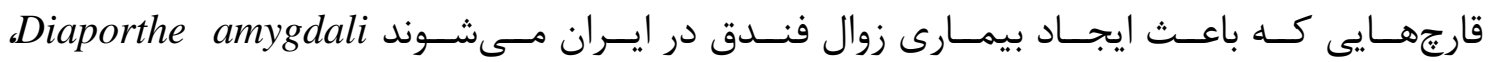
،F. lateritium ،Fusarium semitectum بـاعنوان عاملهــاى شـانكر و Cytospora fuckelii و Armillaria mellea و F. anthophilum نشانههاى زوال درختان فندق در ايران، قارجهاى بيمارگر و راهكارهاى مديريت بيمارى در اين مقالـه شرح داده شدهاند. وازًٔان كليدى: سرخشكيد

\section{مقدمه}

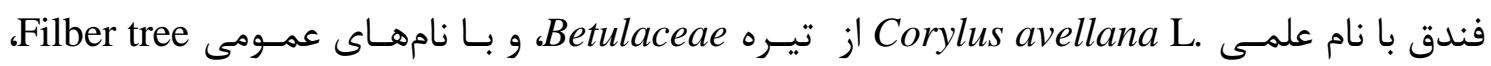
Cobnut tree و Hazelnut tree كونه آن از نظر اقتصادى و بلنزادى اهميت دارد. فندق، درخت كوجى و يا درختجهاى است كه بومى ارويا، آسياى صغير و قفقاز مىباشد (Sabeti 2006). فنـدق داراى رويشـاههاى محسدودى در كشـور است كه عمده آن در مرز جنگل هاى گَيلان و اردبيـل قـرار دارد (Azimi Motamem et al. 2011). رويشگاههاى طبيعى فندق عمدتاً در كمربند فندقخيز كشـور و در منـاطق اشـكورات، نـاوان، تـالش،

$\triangle$ هسئول مكاتبه: mdvari@uma.ac.ir 
دينوجال، گللى داغ، الموت، طارم و فندقلو قرار دارند (Sabeti 2006). بر اساس گزارش فائو (FAO) در

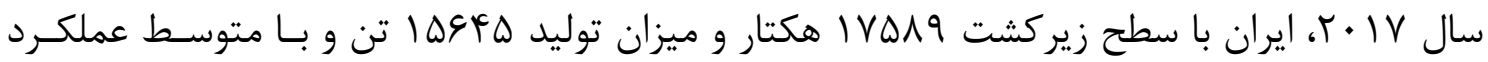

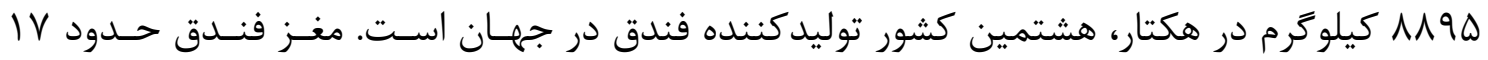

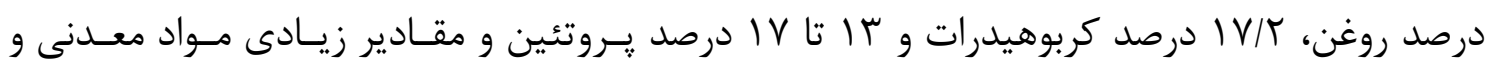
ويتامينها دارد (Ozdemir and Akinci 2004). فندق در صنايع شكلاتسازى نيز مورد استفاده قـرار مى گيرد و از روغن آن در طب و لوازم آرايشى و از جوب آن در مبلسازى و از يوسته سخت آن بـراى

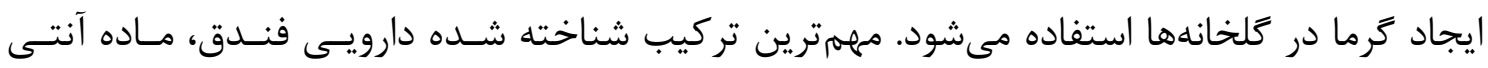
تومورى با نام تجارى Taxol است كه براى درمان انسواع سـرطانها بـه كـار مسىرود ( Hoffman and 2009 Shahidi). مهمترين بيمارى درختان فندق در ايران سرخشكيدگى و زوال آن است.

\section{سرخشكيدىى و زوال درختان فندق}

نشانههاى بيمارى بلهورت كاهش رشد، سرخشكيدگى، شانكر روى شاخه و تنه، كرفتخكى هاى آونسلى و تغيير رنگ جوب محل آوندها، ضعف عمومى، ريزش برك و يوسيدگى ميوه است (شكل () كه منجر

به مرى تدريجى درخت يا زوال در طول ساليان متمادى مىشود(Mirabolfathi et al. 2013).
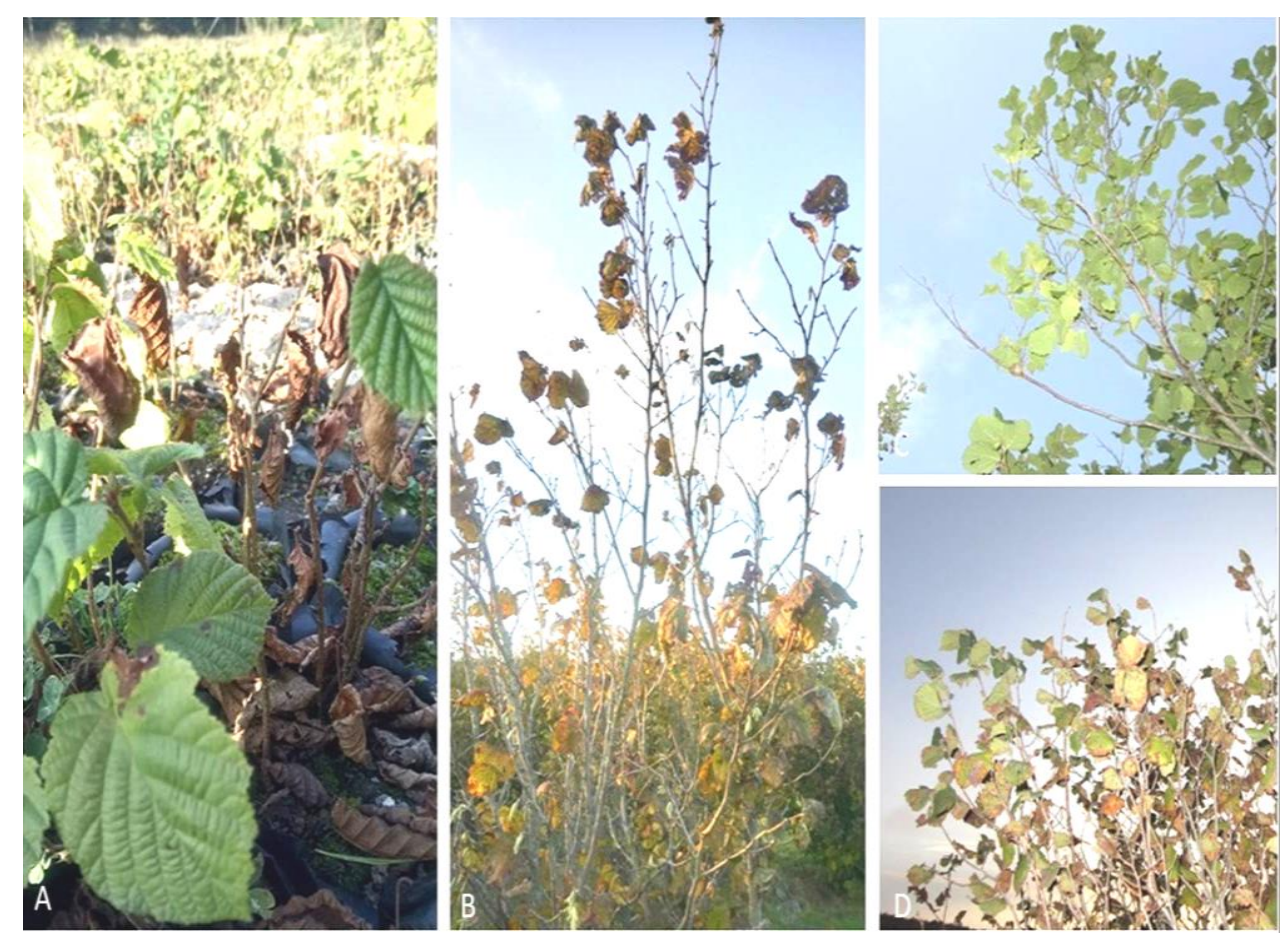

شكل I. A. نشانههاى سرخشكيدگى و زوال در نهالهاى فنـدق، B-D. نشـانههـاى زوال در درختـان فندق (اصلى).

Figure 1. A. Symptoms of dieback and decline in hazelnut seedling, B. Symptoms of decline in hazelnut trees. 
بر اساس يزوهشهايى كه در مورد زوال درختان فندق در ايران انجام ترفتـه اسـت، قـارجهـاى مهـمم دخيل در اين بيمارى به اين شرح هستند.

Diaporthe amygdali (Delacr.) Udayanga, Crous \& K.D. Hyde (=Phomopsis amygdali (Delacr.) J.J. Tuset and M.T. Portilla) اين قارج براى اولين بار در ايران از درختان فندق منطقـهـ اشـكورات اسـتان خــيلان از روى سرشـاخه جداسازى و بيماريزا تشخيص داده شده است (Mirabolfathi et al. 2013). اين قارج با كنيديوماتاى سياه استيولدار و با فياليدهاى استوانهاى بلند و دو نوع كنيديوم شفاف بدون ديـواره يعنى آلفــا و بتــا

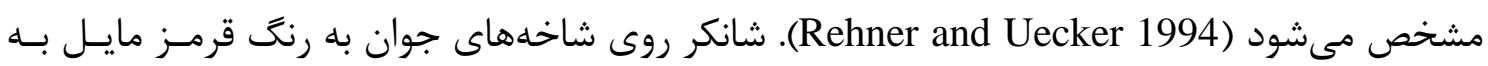
قهوهاى با حاشيه سياه و فرورفته است و ساختارهاى قارجى در بافت يوست بهصورت جوشهاى سـياه

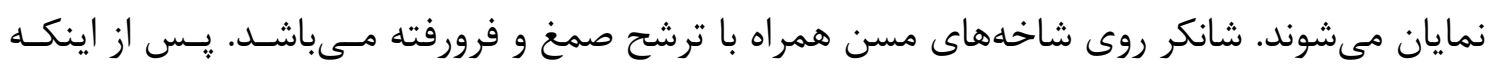

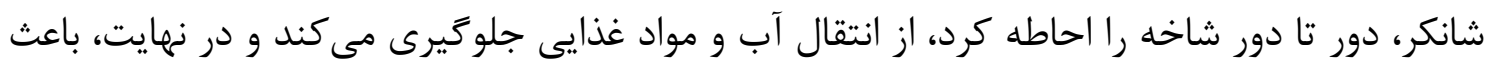

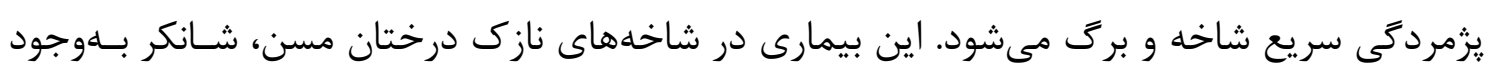

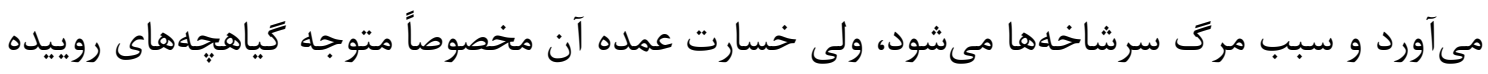

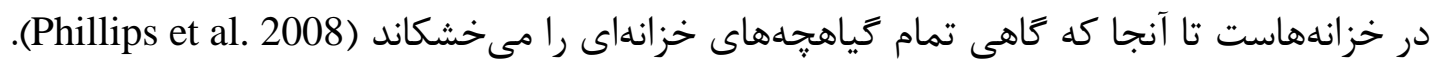

Cytospora ceratosperma (Tode) G.C. Adams \& Rossman (=Cytospora fuckeli Sacc.)

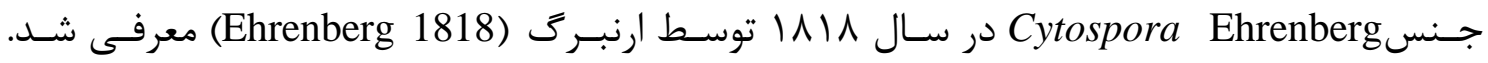
جنس Valseutypella و Valsella Fuckel. ،Valsa Fr..Leucostoma (Nitschke) Höhn. جـاى

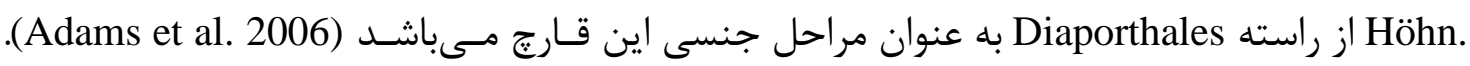

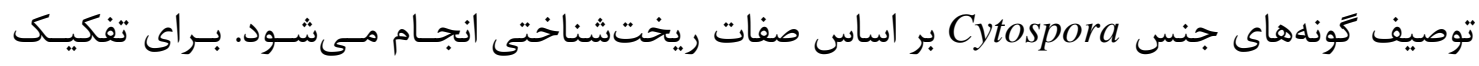

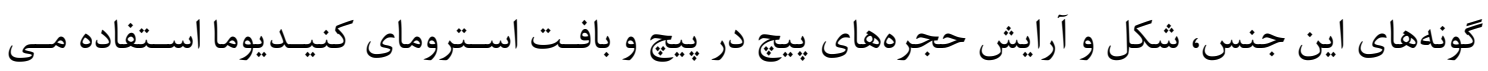
شوند. اين ويزگى ها ممكن است بر حسب ميزبان كياهى تغيير نمايند (Adams et al. 2004).

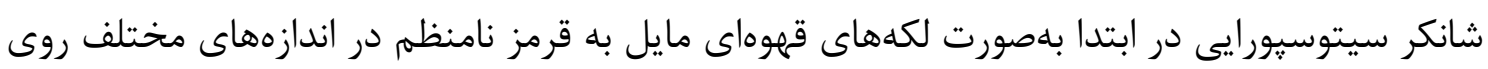

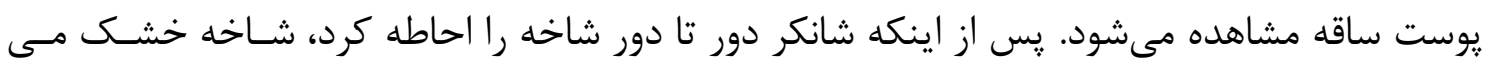

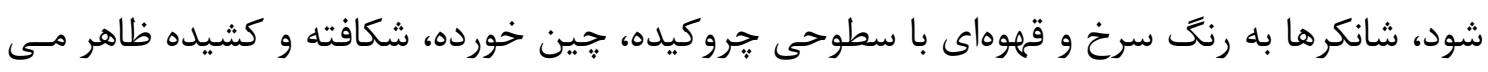

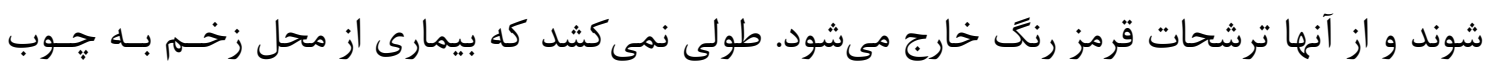

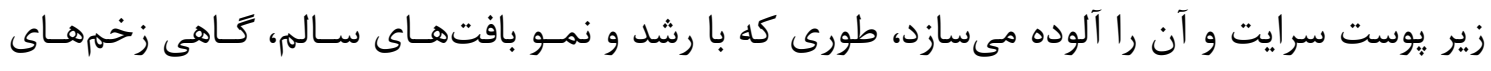

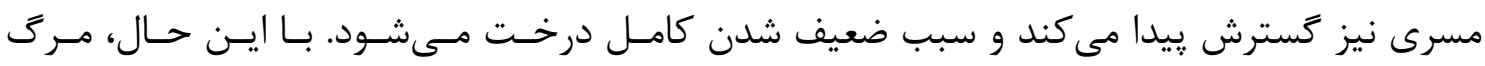

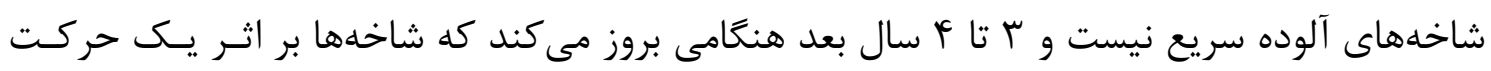


مكانيكى يا اتفاقى از محل بافتهاى زخمى شكسته و جدا مىشوند. يـس از آزمايشهـاى مكـرر و دو

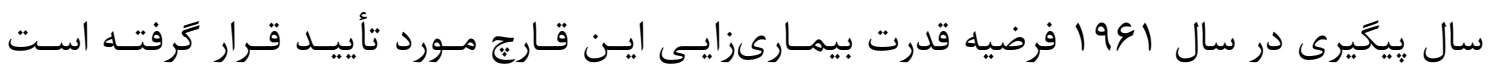
, Cytospora fuckeli Sacc Irا براى اولين بار از آستارا كزارش كردند. همجنين در يزوهشى كه توسط رزاز هاشمى و ذاكرى (I IVq) به منظور تشخيص علل خشكيدگى درختان فندق الموت قزوين انجام گرفـت، C. fuckelii را جداسـازى و شناسـايى نمودنـــ (Ershad 2009). از آنجا كه اين قارج معمـولاً روى ميزبـان ضـعيف رخ مسىدهـد، روش اصـلى مهـار، جلو گيرى از ايجاد تنش روى درخت است. خشكى و كمبود اكسيزن ريشهها و نيـز غرقـاب خـاك، دو تنش شايع است كه درختان را مستعد آلودگى سيتوسيورايى مى كند. به منظور حفظ سلامتى درختان و ي ييشَيرى از اين بيمارى، بايد در نهايت دقت، از درختان فندق نكمهدارى كرد. به اينصـورت كـه در آغاز بايد از كاشت دستهجمعى نهال به شكل انبوه خوددارى كرد. از بين بردن كانون آلودگى به محض مشاهده و ضدعفونى زخمها بعد از هرس يا ساير آسيبديدكىها از روشهاى ديگر مهار است. تاكنون مبارزه شيميايى عليه اين بيمارى از طريق محلولياشى با سمهاى قارجكش مسى و گوگردى در بهـار

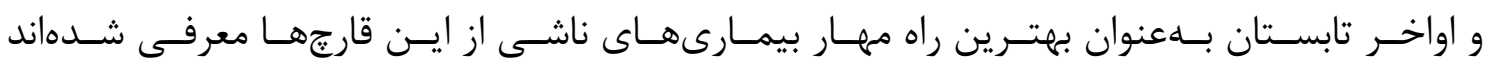

(Lamichhane et al. 2014)

\section{Fusarium species}

جنس Fusarium Link در سال 9.11 معرفى شد. اغلب گونههاى Fusarium در سراسر دنيا در خاى و بقاياى گياهى و اندامهاى هوايى يافت مىشوند (Al-Hatmi 2016). برخى از زونههاى Fusarium سنبله مىشوند (Davari et al. 2013). همجنين مجموعهاى از متابوليتهاى ثانويه سمى مانند تريكوتسين (Trichothecenes)، زرآلنون (Zearalenone)، فومونيزين (Fumonisins) و آنياتينها را توليد مى كنند كه تهديدى جدى براى امنيت كشاورزى، ايمنى مواد غذايى و سلامتى (Aniatins) كياهان، انسانها و حيوانات محسوب مىشود (Marasas et al. 1984). تونههاى Fusarium مى توانند باعث شانكر ساقه به ويزه در نهالستانهاى متراكم شوند (Hansen and Hamm 1988). تونه F. lateritium Nees است و باعث ايجاد يرمردگى، خشكيدگى سرشاخه يا شاخه و شانكر مىشوند. اين قارتج از روى درختان به عنوان بيمارگر زخم به فراوانى گزارش شده است (Gerlach and Nirenberg 1982). Bمجنين اين گونه بهعنوان عامل شانكر درختان فندق در ايتاليا گزارش شده است (2009 Belisario and Santori 


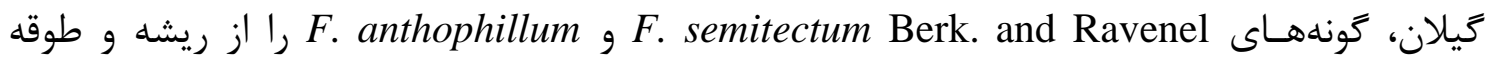
جداسازى و بيماريزا تشخيص دادند. گونهاى Fusarium در بافت يوسيده ميزبان يا در خاك بلهورت كلاميدوسيور باقى مىمانند تا وقتى كه توسط ريشههاى ميزبان تحريك شوند. هات جوانهزه از قسمت ريشه، انتهاى ريشه، تار كشنده و زخمهاى موجود در محل انشعاب ريشه فرعى، وارد ريشه مىشود. قارج عامل بيمارى بهصورت بين سلولى حركت كرده و داخل يوست ريشه مىشود و از سوراخهاى بين آوندى، وارد آوندهاى جوبى شده و به قسمتهاى بالا، به سمت طوقه و ساقه گياه حركت مى كند. در اين هنگام، مسيليوم درون آوند حركت مى كند و ميكروكنيديومها توليد شده و با شيره گياهى به سمت بالا مىروند. نشانههاى يزمردگى در اثر انسداد آوندها با مسيليوم، هاگ، توليد توكسين و ياسخهاى دفاعى ميزبان مانند مواد زلهاى و تيلوزها اتفاق مىافتد. در اثر انسداد آوندى، گياه خشك شده و بعد از مرى گياه، قارج عامل بيمارى به سطح گياه مرده مىرسد و در آنجا هاگ فراوان توليد مى كند. هاگهاى توليد شده از طريق آب، باد و غيره به گياهان جديد منتقل شده و در خاك به صورت كلاميدوسيور بقا دارند (Smith 2007). استفاده از رقمهاى مقاوم در برابر اين قارجهاى بيمارىزا، بهترين اثر را در كاهش بيمارى دارد. روشهاى زراعى و شيميايى هم تا حدودى بيمارى را مهار مى كنند. استفاده از قارجكشهاى گروه

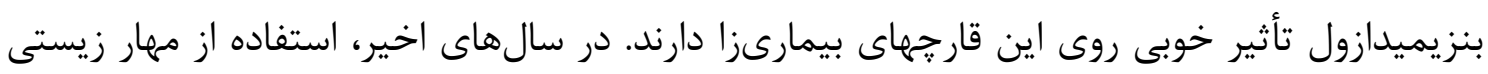
نتايج خوبى به همراه داشته است. مهار زيستى با استفاده از سويههاى غير بيماريزاى Trichoderma Gliocladium Corda قارجهاى متعارض از جنسهاى F. oxysporum Schltdl Bacillus ،Pseudomonas Migula و باكترىهايى از جنسهاى (Sivan and Chet 1986)Pers.

Burkholderia Yabuuchi و انجام گرفته است (Hadwig and Defago 2005).

\section{Armillaria mellea (Vahl) P. Kumm}

اين قارج باعث يوسيدگى ريشه و طوقه دامنه وسيعى از درختان ميوه، جنگلى و فضاى سبز وارد مسى

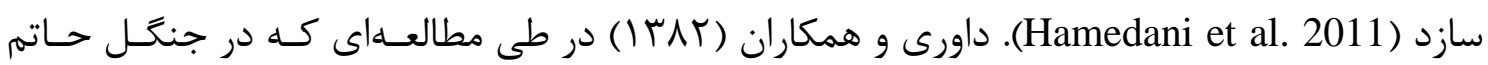
بيگَ مشگينشهر به منظـور تشـخيص علـل زوال و مـرى درختـان بلـوط سـياه انجـام دادنـد، قـارج را بهعنوان مهمترين عامل يوسيدگى ريشـه و ايجـاد زوال ايسن درختـان معرفىى Armillaria mellea

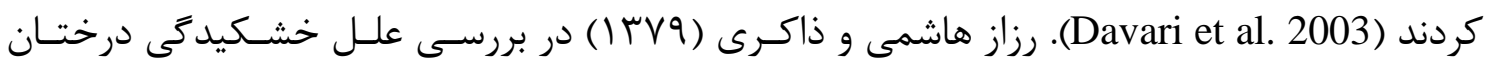
فندق الموت قزوين، قارج Armillaria mella را جداسازى و شناسايى نمودند (Ershad 2009).

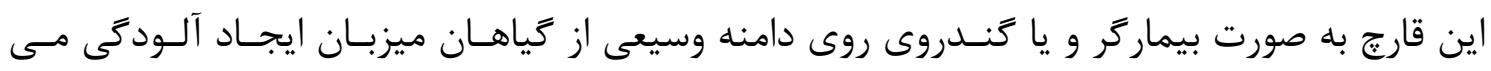
نمايند (Coetzee et al. 2003). درختان بيمار به تدريج ولى بى وقفه دجار زوال مىشوند يا كاهى مى لى 
خشكند. بر اثر اين بيمارى، تعداد درختانى كه در دوره تنش رطوبتى دجار نابودى يـا بركىريـزى مسى

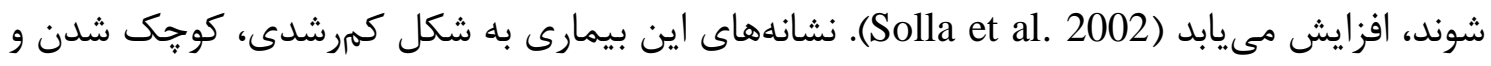

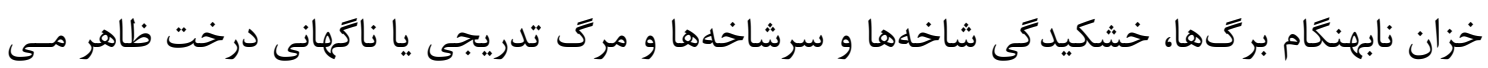

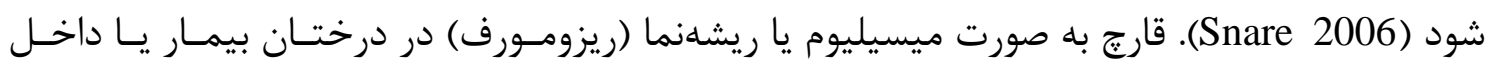
ريشههاى در حال فساد زمستان گذرانى مى كند. روش اصلى انتشار قارج از درختى به درخت ديخـر بـا

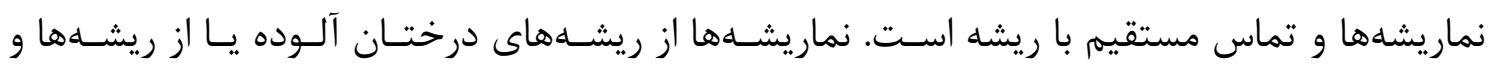

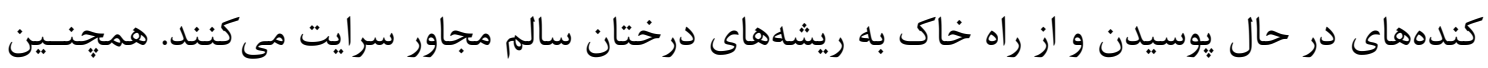

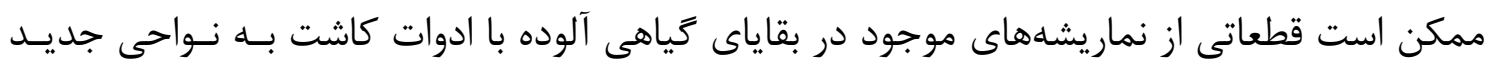

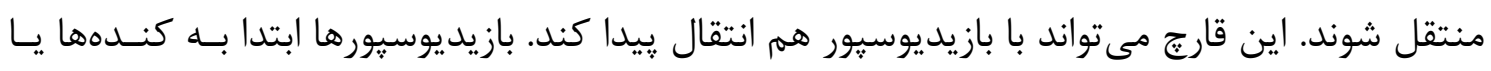

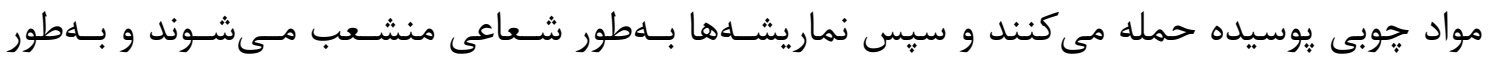
مستقيم يا از راه زخم، به ريشههاى در حال رشد و زنده هجوم مىبرند. در هر حال، درختـان ضعيف

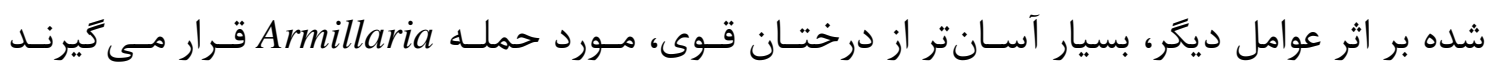

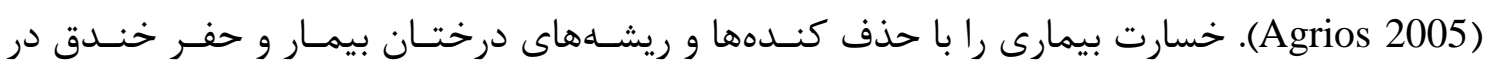

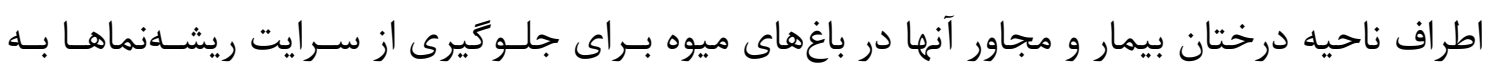

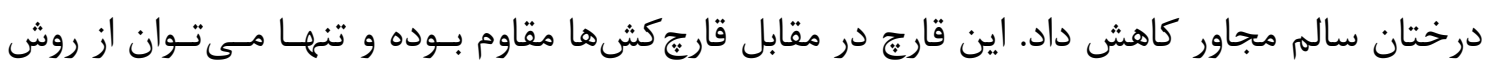
تدخين موضعى قبل از كاشتن درختان استفاده كرد (Sipos et al. 2018, Agrios 2005 ).

\section{نتيجه}

يديده زوال باعث نابودى و مرك تدريجى درختان فندق مىشود و در اثر عوامل متعدد زنده و غيرزنده

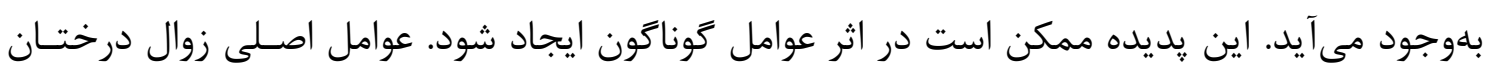

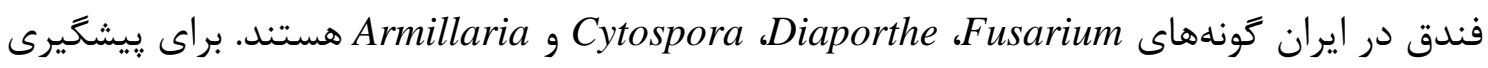

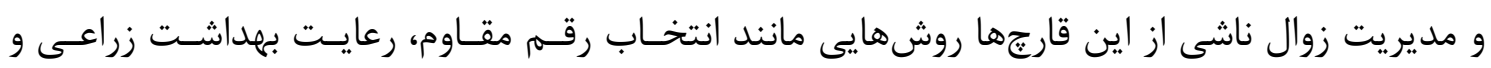

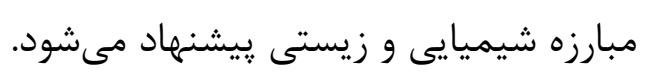

\section{References}

منابع

1. Adams GC, Roux J, Wingfield MJ (2006) Cytospora species (Ascomycota, Diaporthales, Valsaceae): introduced and native pathogens of trees in South Africa. Australasian Plant Pathology 35:521-548. 
2. Adams GC, Wingfield MJ, Common R, Roux J (2004). Phylogenetic relationships and morphology of Cytospora species and related teleomorphs (Ascomycota, Diaporthales, Valsaceae) from Eucalyptus. Studies in Mycology 52.

3. Agrios GM (2005) Plant Pathology. Academic Press, New York, USA, 948p.

4. Al-Hatmi AMS, Meis JF, de Hoog GS (2016) Fusarium: Molecular diversity and intrinsic drug resistance. PLoS Pathogens 12:e1005464.

5. Azimi Motamem F, Talaei R, Asia Zadeh F, Hoshyar M (2011) A survey on flora, life forms and geographical distribution of plant species in the protected forests of Fandoghlu (Ardabil province). Taxonomy and Biosystematics 3:75-88.

6. Belisario A, Santori A (2009) Gray necrosis of hazelnut fruit: a fungal diseasecausing fruit drop. Acta Horticulturae 845:501-506.

7. Coetzee MP, Wingfield BD, Bloomer P, Ridley GS, Wingfield MJ (2003) Molecular identification and phylogeny of Armillaria isolates from South America and IndoMalaysia. Mycologia 95:285-293.

8. Davari M, Payghami E, Javanshir A, Ebrahimi T (2003) Etiology of Oak (Quercus macranthera) Decline in Hatam-Baig Forest of Meshkinshahr area. Agricultural Science 13:1-14.

9. Davari M, Wei S, Babay-Ahari A, Arzanlou M, Waalwijk C, van der Lee TA, Zare R, Gerrits van den Ende A, De Hoog G, Van Diepeningen A (2013) Geographic differences in trichothecene chemotypes of Fusarium graminearum in the Northwest and North of Iran. World Mycotoxin Journal 6:137-150.

10. Ershad J (2009) Fungi of Iran. Iranian Research Institute of Plant Protection Press, Iran, 531p. (In Persian).

11. Fan XL, Hyde KD, Udayanga D, Wu XY (2016) Diaporthe rostrata, a novel ascomycete from Juglans mandshurica associated with walnut dieback. Mycological Progress 14:1-8.

12. FAO (Food and Agriculture Organization of the United Nations) (2017) FAO Statistical Databases. Available at http://www.fao.org/.

13. Gerlach W, Nirenberg HI (1982) The Genus Fusarium-A pictorial atlas. Mitteilungen aus der Biologischen Bundesanstalt für Land-und Forstwirtschaft. Berlin-Dahlem 209:1-406.

14. Gomes RR, Glienke C, Videira SIR, Lombard L (2013) Diaporthe, a genus of endophytic, saprobic and plant pathogenic fungi. Persoonia 31:1-41.

15. Guarro J (2013) Fusariosis, a complex infection caused by a high diversity of fungal species refractory to treatment. Diagnostic Microbiology and Infectious Disease 32:1491-500. 
16. Haas D, Défago G. (2005) Biological control of soil-borne pathogens by fluorescent Pseudomonads. Nature Reviews Microbiology 3:307-319.

17. Hamedani A, Sharif Nabi B , Bahar M (2012) Application of classical and molecular techniques in detection of Armillaria mellea the causal agent of root and crown rot disease from soil and wood. Iranian Journal of Plant Pathology 48:235-223 (In Persian with English Abstract).

18. Hansen EM, Hamm PB (1988) Canker diseases of Douglas-fir seedlings in Oregon and Washington bareroot nurseries. Canadian Journal of Forest Research 18:1053-1058.

19. Hoffman A, Shahidi F (2009) Paclitaxel and other taxanes in hazelnut. Journal of Functional Foods 1:33-37.

20. Hood IA, Redfern DB, Kile GA (1991) Armillaria in Plant Hosts. Pp.122-149, In: CG Shaw GA Kile (ed.). Armillaria Root Disease. U.S. Forest Service: Washington, USA.

21. Lamichhane JR, Fabi A, Varvaro L (2014) Summer heat and low soil organic matter influence severity of hazelnut Cytospora canker. Phytopathology 104:387-95.

22. Marasas WFO, Nelson PE, Toussoun TA (1984) Toxigenic Fusarium species: identity and mycotoxicology. University Park, Pennsylvania, USA: The Pennsylvania State University Press. 220p.

23. Mir Hosseini Moghaddam SA, Taherzadeh M (2007) Isolated fungi from hazelnut, their damage and economic importance in Guilan province. Iranian Journal of Forests and Rangelands Protection Research 5:98-96. (In Persian with English Abstract).

24. Mirabolfathi M, Hoseinian L, Mir Hosseini Moghaddam A (2013) First report of Phomopsis amygdali (Del.) tuset and portilla, the causing galls on common hazelnut (Corylus avellana) twigs in Iran. Iranian Journal of Plant Pathology 49:132-133. (In Persian with English Abstract).

25. O'Donnell K, Ward TJ, Robert ARG, Crous WP, Geiser DM (2015) DNA sequence-based identification of Fusarium: current status and future directions. Phytoparasitica 43:583-595.

26. Ozdemir F, Akinci I (2004) Physical and nutritional properties of four major commercial Turkish hazelnut varieties. Journal of Food Engineering 63:341-347.

27. Phillips AJL, Alves A, Pennycook SR, Johnston PR, Ramaley A, Akulov, Crous PW (2008) Resolving the phylogenetic and taxonomic status of dark-spored teleomorph genera in the Botryosphaeriaceae. Persoonia: Molecular Phylogeny and Evolution of Fungi 21:29. 
28. Rehner SA, Uecker FA (1994) Nuclear ribosomal internal transcribed spacer phylogeny and host diversity in the coelomycete Phomopsis. Canadian Journal of Botany 72:1666-1674.

29. Sabeti HA (2006) Forest, Trees and Shrubs of Iran. Yazd University Press, Yazd, Iran, 876 p. (In Persian).

30. Santos JM, Phillips AJL (2009) Resolving the complex of Diaporthe (Phomopsis) species occurring on Foeniculum vulgare in Portugal. Fungal Diversity 34:111-125.

31. Sipos G , Anderson JB, Nagy LG (2018) Armillaria. Current Biology 28:297298.

32. Sivan A, Chet I (1986) Biological control of Fusarium spp. in cotton, wheat and musk melon by Trichoderma harzianum. Journal of Phytopathology 116:39-47.

33. Smith SN (2007) An overview of ecological and habitat aspects in the genus Fusarium with special emphasis on the soil - borne pathogenic forms. Plant Pathology 16:97-120.

34. Solla A, Tomlinson F and Woodward S (2002) Penetration of Picea sitchensis root bark by Armillaria mellea, Armillaria ostoyae and Heterobasidion annosum. Blackwell Wissenschafts-Verlag, Berlin, 55-70.

35. Sutton BC (1980) The coelomycetes. Fungi imperfecti with pycnidia, acervuli and stromata. Commonwealth Mycological Institute, England.

36. Van Niekerk JM, Groenewald JZ, Farr DF, Fourie PH, Halleen F, Crous PW (2011) Reassessment of Phomopsis species on grapevines. Australasian Plant Pathology 34:27-39.

37. Wiman NG, Webber III JB, Wiseman M, Merlet L (2019) Identity and pathogenicity of some fungi associated with hazelnut (Corylus avellana L.) trunk cankers in Oregon. Plos One 14:e0223500. 